\title{
Incompatibility of Tuberculin Skin Test and Interferon Gamma Release Assay; LTBE or not?
}

\author{
Tüberkülin Deri Testi ve Interferon Gama Salınım Testleri Uyumsuzluğu; \\ LTBE mi Değil mi?
}

\author{
Beyhan Bülbül(iD), Mustafa Hacımustafaoğlu(ID) \\ Division of Pediatric Infectious Diseases, Department of Pediatrics, Uludag University School of Medicine, Bursa, Turkey
}

Question: While the 22-month-old boy was being evaluated because of contact with a patient (grandfather) with bacillary tuberculosis, the TST test was found to be $16 \mathrm{~mm}$. The baby still has no complaints and seems healthy. In the clinical and laboratory evaluation of the baby, active tuberculosis (TB) was not detected and single drug therapy (INH prophylaxis) was recommended for latent tuberculosis infection (LTBI). However, the family later voluntarily had a Quantiferon test done in a private laboratory and the result was reported as negative. Should this child, whose records are found to have a BCG vaccine, be given single-drug therapy (INH prophylaxis) prophylaxis for LTBI? Md. Fatma Betül Seymen

Cite this article as: Bülbül B, Hacımustafaoğlu M. Incompatibility of tuberculin skin test and interferon gamma release assay; LTBE or not? J Pediatr Inf 2021;15(3):e197-e199.

\section{Answer (Beyhan Bülbül, MD; Mustafa Hacımustafaoğlu, MD)}

Introduction and general information: First of all, it will be useful to review some information that can form the basis of the answer. Tuberculosis infection (Latent tuberculosis infection; LTBE) is defined as the development of acquired bacteria-induced immune recognition (T-cell response) in an individual after infected with tuberculous bacteria (Mycobacterium tuberculosis) without clinical or laboratory signs of disease. LTBI is diagnosed in a child who is clinically and radiologically completely normal, with the positivity of tuberculin skin test (TST) or interferon gamma release assays (IGRAs), which indicate that the bacteria has been taken and a cellular response has developed against it. In order for these tests to give positive results, a period of 8-10 weeks (roughly 3 months) should pass from the entry of the M. tuberculosis bacteria into the body.
A child with LTBI appears completely normal and has no clinical or radiological findings. However, they carry the risk of developing clinical TB disease (pulmonary TB or Extrapulmonary TB) in the future. The person with LTBI may develop TB disease later in life; $5-15 \%$ in adults, and may be higher if there are additional risk factors. The risk is higher in children (eg $50 \%$ in babies $<1$ year old, $25 \%$ between $1-2$ years old) . About half of them develop TB disease within the first 2 years. In a recent study conducted in the USA and Canada, it was shown that active TB disease developed in $4 \%$ of adults $(>15$ years) within the first 3 months aftercontact of an infectious TB case. Therefore, the possible high risk requires preventive treatment in individuals with LTBI.

Evaluation of TST positivity and positive TST criteria may differ from country to country. In this regard, the criteria of classical scientific sources (mostly American) may be slightly different from the criteria accepted in Turkey. Also, in TST evaluation, positive TST criteria may differ with various factors

\section{Correspondence Address / Yazışma Adresi}

Mustafa Hacımustafaoğlu

Uludağ Üniversitesi Tıp Fakültesi,

Çocuk Sağlığı ve Hastalıkları Anabilim Dalı,

Çocuk Enfeksiyon Hastalıkları Bilim Dalı,

Bursa-Türkiye

E-mail: mkemal@uludag.edu.tr 
and situations. Some of these include; high incidence of TB disease in the region where the child lives, previous BCG vaccination status, age group (young children are in the high risk), situations where the risk of developing disseminated TB disease after LTBI is expected to be high (for example, TST is considered positive $>10 \mathrm{~mm}$ in children $<4$ years old), suppression of the immune system (TST positivity is considered as $>5 \mathrm{~mm}$ ), the presence of clinical and radiological findings suggestive of TB (TST positivity is accepted as $>5 \mathrm{~mm}$ ), close contact with a contagious TB patient (TST positivity is considered as $>5 \mathrm{~mm}$ ). Performing the TST with the appropriate technique and measuring it correctly also affects the TST result. The fact that TST is affected by BCG vaccine (eg the risk of false positivity in BCG vaccinees) is one of its most important drawbacks. The ability of the BCG vaccine to affect TST weakens over the years. In general, medical literature interpret TST independently of BCG vaccine status and use the same criteria for vaccinated and unvaccinated. In Turkey, a TST positivity is generally considered to be $>15 \mathrm{~mm}$ in children with a healthy immune system, if they are vaccinated, $>10 \mathrm{~mm}$ if they are unvaccinated, and $>5$ $\mathrm{mm}$ in children with a suppressed immune system.

Interferon gamma release tests (IGRAs) allow the detection of previously sensitized T lymphocytes in the blood that recognize specific antigens for $M$. tuberculosis. Unlike TST, it is an in vitro test. Its positivity suggests the diagnosis of LTBI. IGRA is not affected by the BCG vaccine, which is an advantage in a vaccinated child. Studies conducted in children aged $>2$ years, it has been shown that IGRA is more specific than TST. However, it should be kept in mind that IGRA is much more expensive than TST, and tests are not available everywhere. In addition, inadequate blood collection and laboratory working conditions (such as delay in sample processing, incubator malfunction, technical errors) may also affect the quality of the test. High rates of indeterminate IGRA results have especially been reported in children $<5$ years of age tested with IGRA.

Which LTBI diagnostic test (TST or IGRAs) should be preferred?: Generally $<2$ years or $<5$ years TST is preferred to IGRAs. IGRA tests if available, can be preferred, especially for people over 2-5 years old, especially those vaccinated with BCG. However, there is insufficient evidence to recommend a choice between TST or IGRAs if there is a history of contact with a contagious person aged $>5$ years or if there is a high risk of conversion to TB disease. In addition, even at the age of $>5$ years, TST is considered an acceptable alternative if there is no opportunity for IGRAs (such as no laboratory, test can not be performed, cannot be performed due to cost). Having an experienced healthcare worker for TST can also increase confidence in TST.

Would it be appropriate to run both tests in each patient, if available?: In general, there is no recommendation for routine testing of both tests for the same patient to diag- nose LTBI. According to the American Thoracic Society (ATS) and the Infectious Diseases Society of America (IDSA), no testing is indicated if a patient has a low risk of TB infection and a low risk of progression in a developing disease. If a test has been done and if it is positive, it is necessary to repeat it with another test (TST or IGRAs), and if both test results are positive, LTBI should be considered. In Turkey, the recommended test under 5 years of age is TST, and confirmation of the patient with IGRAs is not routinely recommended.

Within the framework of these general approaches, the answer to the question is;

1. First of all, this 22-month-old baby is in the high-risk group both for the development of TB disease (as well as the development of disseminated TB disease) because she is $<4$ years old, and for being in close contact with an infectious adult.

2. According to the American Academy of Pediatrics (AAP), in children $<2$ years old, and according to the Turkish Ministry of Health guidelines and ATS/IDSA in children $<5$ years old, TST is a preferred diagnostic method for LTBI over IGRAs. Therefore, TST is the diagnostic approach to be preferred in this patient. Checking the result with a second test in a risky age group for which TST is recommended is not recommended routinely in the world and in our country. Therefore, IGRAs are not recommended for such a high-risk patient who has undergone TST.

3. Actually, according to classical information ; if there is $>5 \mathrm{~mm}$ TST response in children who have close contact with an infectious adult, and $>10 \mathrm{~mm}$ in children aged $<4$ years, even if there is no history of contact (independent of BCG vaccine), it is recommended to consider the diagnosis of LTBI and give prophylactic treatment.

In conclusion and briefly; In Turkey, according to the Ministry of Health guideline, this baby with a positive TST ( $16 \mathrm{~mm}$; vaccinated and having $>15 \mathrm{~mm}$ TST) should be consideed as LTBI. She should be considered a risk group, would be appropriate to receive treatment with a single drug (prophylactic treatment) with the diagnosis of LTBI.

\section{References}

1. T.C. Sağıık Bakanlığı. Tüberküloz Tanı ve Tedavi Rehberi, 2. Baskı Ankara 2019. Ed: Kara F. Available from: https://hsgm.saglik.gov.tr/depo/birimler/tuberkuloz_db/haberler/Tuberkuloz_Tani_Ve_Tedavi_Rehberi_/ Tuberkuloz_Tani_ve_Tedavi_Rehberi.pdf. Accessed: 12 October 2021. [CrossRef]

2. Menzies D. Approach to diagnosis of latent tuberculosis infection (tuberculosis screening) in adults.Ed: von Reyn CF. Available from: $h$ ttps:// www.uptodate.com/contents/approach-to-diagnosis-of-latent-tuberculosis-infection-tuberculosis-screening-in-adults? Accessed: 12 October 2021. [CrossRef] 
3. Lewinsohn DM, Leonard MK, LoBue PA, Cohn DL, Caley DL, Desmond $E$, et al. Official American Thoracic Society/Infectious Diseases Society of America/Centers for Disease Control and Prevention Clinical Practice Guidelines: Diagnosis of Tuberculosis in Adults and Children. Clin Infect Dis 2017;64:e1. [CrossRef]

4. Reichler MR, Khan A, Sterling TR, Zhao H, Moran J, McAuley J, et al. Risk and timing of tuberculosis among close contacts of persons with infectious tuberculosis. J Infect Dis 2018;218:1000-8. [CrossRef]

5. American Academy of Pediatrics. Tuberculosis. In Red Book: 2021-2024. Report of the Committee on Infectious Diseases, 32nd ed, Kimberlin DW, Barnett ED, Lynfield R, Sawyer MH (Eds), American Academy of Pediatrics, Itasca, IL 2021.p786-814. [CrossRef]

6. Adams LV, Starke JR. Latent tuberculosis infection in children. Eds: von Reyn CF, Edwards MS. Available from: https://www.uptodate.com/ contents/latent-tuberculosis-infection-in-children?search=tuberculous\%20infection\%20diagnosis\&source=search_result\&selectedTitle $=4 \sim 150 \&$ usage_type $=$ default\&display_rank=4. Accessed: 12 October 2021. [CrossRef]

7. Guidelines for the Treatment of Latent Tuberculosis Infection: Recommendations from the National Tuberculosis Controllers Association and CDC, 2020. MMWR Recomm Rep 2020; 69: 1-11. [CrossRef]

8. Ahmed A, Feng PI, Gaensbauer JT, Reves RR, Khurana R, Salcedo K, et al. Interferon- $\gamma$ Release Assays in Children $<15$ Years of Age. Pediatrics 2020;145. [CrossRef]

9. Soler-Garcia A, Gamell A, Santiago B, Monsonis M, Calvo C, Cobo E, et al. Diagnostic Accuracy of QuantiFERON-TB Gold Plus assays in children and adolescents with tuberculosis disease. J Pediatr 2020;223:212. [CrossRef]
10. Ferrara G, Losi M, D'Amico R, Roversi P, Piro R, Meacci $M$, et al. Use in routine clinical practice of two commercial blood tests for diagnosis of infection with Mycobacterium tuberculosis: a prospective study. Lancet 2006;367:1328-34. [CrossRef]

11. Zellweger JP, Sotgiu G, Block M, Dore S, Altet N, Blunschi R, et al. TBNET. Risk assessment of tuberculosis in contacts by IFN- $\gamma$ release assays. $A$ Tuberculosis Network European Trials Group Study. Am J Respir Crit Care Med 2015;191:1176-84. [CrossRef]

12. Bergamini BM, Losi M, Vaienti F, D'Amico R, Meccugni B, Meacci M, et al. Performance of commercial blood tests for the diagnosis of latent tuberculosis infection in children and adolescents. Pediatrics 2009;123:e419-24. [CrossRef]

13. Kampmann B, Whittaker E, Williams A, Walters S, Gordon A, Martinez-Alier $N$, et al. Interferon-gamma release assays do not identify more children with active tuberculosis than the tuberculin skin test. Eur Respir J 2009;33:1374-82. [CrossRef]

14. Adams LV, Starke JR. Tuberculosis disease in children. Eds: von Reyn CF, Edwards MS. Available from: https://www.uptodate.com/contents/ tuberculosis-disease-in-children?search=TUBERCULOS\%C4\%BOS\%20 $\% C 4 \% B O N \% 20 C H \% C 4 \% B O L D R E N \&$ source=search_result\&selectedTitle $=1 \sim 150 \&$ usage_type=default\&display_rank=1. Accessed: 12 October 2021. [CrossRef]

15. Tuberculosis: Current Concepts and Treatment, $2^{\text {nd }}$ ed, Friedman $L N$ (Ed), CRC Press, Boca Raton 2001. [CrossRef] 